This Accepted Author Manuscript is copyrighted and published by Elsevier. It is posted here by agreement between Elsevier and University of Brasilia. Changes resulting from the publishing process - such as editing, corrections, structural formatting, and other quality control mechanisms - may not be reflected in this version of the text. The definitive version of the text was subsequently published in [International Journal of Insect Morphology and Embryology, Volume 27, Issue 3, 1 July 1998, Pages 235-240, doi:10.1016/S0020-7322(98)00015-4].You may download, copy and otherwise use the AAM for non-commercial purposes provided that your license is limited by the following restrictions:

(1) You may use this AAM for non-commercial purposes only under the terms of the CC-BY-NCND license.

(2) The integrity of the work and identification of the author, copyright owner, and publisher must be preserved in any copy.

(3) You must attribute this AAM in the following format: [agreed attribution language, including link to CC BY-NC-ND license + Digital Object Identifier link to the published journal article on Elsevier's ScienceDirect ${ }^{\circledR}$ platform].

Este Manuscrito do Autor Aceito para Publicação (AAM) é protegido por direitos autorais e publicado pela Elsevier. Ele esta disponível neste Repositório, por acordo entre a Elsevier e a Universidade de Brasília. As alterações decorrentes do processo de publicação - como a edição, correção, formatação estrutural, e outros mecanismos de controle de qualidade - não estão refletidas nesta versão do texto. A versão definitiva do texto foi posteriormente publicado em [International Journal of Insect Morphology and Embryology, Volume 27, Número 3, 1 de Julho de1998, Páginas 235-240, doi:10.1016/S0020-7322(98)00015-4]. Você pode baixar, copiar e utilizar de outra forma o AAM para fins não comerciais, desde que sua licença seja limitada pelas seguintes restrições:

(1) Você pode usar este AAM para fins não comerciais apenas sob os termos da licença CC- BYNC-ND.

(2) A integridade do trabalho e identificação do autor, detentor dos direitos autorais e editor deve ser preservado em qualquer cópia.

(3) Tem de atribuir este AAM no seguinte formato: [acordo na linguagem atribuída, incluindo o link para CC BY-NC-ND licença Digital + DOI do artigo publicado na revista Elsevier ScienceDirect ${ }^{\circledR}$ da plataforma]. 


\title{
Contribution of the golgi Complex-Endoplasmic reticulum system during spermiogenesis in three species of phytophagous bugs (Hemiptera : Pentatomidae)
}

Adrienne P Fernandes

Guilherme Curi

Sônia N Báo

\begin{abstract}
The participation of the Golgi complex-endoplasmic reticulum system during spermiogenesis in 3 species of phytophagous bugs (Acrosternum aseadum, Euchistus heros and Nezara viridula) were analysed at the ultrastructural level, after postfixation with osmium tetroxide \potassium iodide. Intense staining was found in the nuclear envelope, endoplasmic reticulum cisternae, Golgi complex, and in a meshwork of tubules scattered throughout the cytoplasm. It is shown that these compartments present a reducing environment. The presence of this kind of staining on the spermatid suggests an important participation of these structures on the differentiation process of this cell.
\end{abstract}

Keywords: Cell differentiation; potassium iodide; trasmission electron microscopy; osmium impregnation; Acrosternum aseadum; Euchistus heros; Nezaraviridula

\section{Introduction}

The spermatozoa are very specialized and highly differentiated cells. They have lost various organelles essential to cell metabolism, while the remaining organelles are modified in a manner unparalleled in other processes of cell differentiation. The main compartment of a typical insect spermatozoon are the head, containing the nucleus and acrosome, and the tail, which contains the axoneme and mitochondrial derivatives (for reviews, see Phillips, 1970; Baccetti, 1972).

The sperm nucleus development is characterized by 2 phenomena : the change from a spherical to a highly asymmetric configuration, and the chromatin conversion from a dispersed to a very condensed state (Fawcett et al., 1971; Tokuyasu, 1974). The acrosome, rich in hydrolases, is covered by the acrosomal and plasma membranes (Baccetti, 1972; Báo et al., 1989).

The sperm tail is characterized by a 9+9+2 microtubular pattern in the axoneme, flanked by 2 mitochondrial derivatives containing crystalline material (Phillips, 1970). Heteropteran spermatozoa have certain characteristics in common that are not found in other insects : 2-3 crystalline bodies within the mitochondrial derivatives and bridges between the 
mitochondrial derivatives and 2 of the axonemal microtubular doublets (Afzelius et al., 1976; Dallai and Afzelius, 1980; Dolder, 1988; Báo and de Souza, 1994a).

Scanty information is available on the Golgi complex-endoplasmic reticulum system of insects germ-cells. Cytochemical data in spermatids of mosquitoes showed the presence of acid phosphatase activity, demonstrating the participation of these compartments in the differentiation process of spermatids (Ndiaye and Mattei, 1992; Báo and de Souza, 1994b).

In the present study, we analyse at the ultrastructural level the morphology of the Golgi complex-endoplasmic reticulum system during spermiogenesis of three species of phytophagous bugs after postfixation of the cells with OsO4\KI.

\section{Materials and methods}

The insects utilized were male adults of the phytophagous bugs Acrosternum aseadum, Euchistus heros, and Nezara viridula (Hemiptera : Pentatomidae), obtained from a colony maintained in the National Center of Genetic Resource (CENARGEN), Brasília-Brazil.

\subsection{Transmission electron microscopy}

The testes were dissected and fixed for $2 \mathrm{~h}$ in a solution containing $2.5 \%$ glutaraldehyde, $4 \%$ paraformaldehyde, $3 \%$ sucrose and $5 \mathrm{mM} \mathrm{CaCl} 2$ in $0.1 \mathrm{M}$ cacodylate buffer, $\mathrm{pH}$ 7.2. After fixation, the specimens were rinsed in buffer, and postfixed in $1 \%$ osmium tetroxide, $0.8 \%$ potassium ferricyanide, and $5 \mathrm{mM} \mathrm{CaCl} 2$ in the same buffer. The material was dehydrated in acetone and embedded in Spurr resin.

\subsection{Osmium tetroxide\potassium iodide impregnation}

The testes were fixed for $2 \mathrm{~h}$ with $2.5 \%$ glutaraldehyde in $0.1 \mathrm{M}$ cacodylate buffer $\mathrm{pH}$ 7.2, washed once in the same buffer, twice in a solution of $1 \%$ potassium iodide (KI) in distilled water and then left for $48 \mathrm{~h}$ at room temp. in the dark in a 1\% OsO4-1\% $\mathrm{KI}$ solution (Locke and Huie, 1983). Thereafter, the specimens were washed with $1 \% \mathrm{KI}$ in distilled water, dehydrated in acetone and embedded in Spurr resin.

Ultrathin sections, unstained or stained with uranyl acetate and lead citrate, were observed by transmission electron microscope. 


\section{Results}

Spermiogenesis in insects involves nuclear elongation, chromatin condensation, acrosomal formation, and flagellar development, along with formation of the axoneme as well as mitochondrial derivatives. This process involved the Golgi complex-endoplasmic reticulum system.

During the early spermatid phase, the nucleus resembles that of a somatic cell. The surrounding cytoplasm contained a well-developed Golgi complex and mitochondrial complex (Fig. 1A). The spermatid axoneme contained a variety of tubular elements that persisted in the spermatozoon. There were 9 accessory microtubules followed by 9 doublets and a central pair of microtubules (Fig. 1B). Two mitochondrial derivatives, containing 2 or 3 paracrystalline structures, flanked the axoneme (Fig. 1B).

In the early spermatid, a single Golgi complex close to the proacrosomal granule was observed (Fig. 1C). Occasionally, it appeared near the flagellar components (Fig. 1D).Although the Golgi complex typically appeared as a flattened structure, circular and U-shaped patterns were also frequently observed (Fig. 1 C, E). It is made up of 8-10 saccules, with the central saccule showing a uniform thickness and electron-dense contents; it is not fenestrate, which clearly differentiates it from the other saccules.

An elongated cisterna of the endoplasmic reticulum was associated to the cis face of the Golgi complex; several uncoated vesicules were found between the endoplasmic reticulum and the first Golgi cistern, forming a cis Golgi network (Fig. 1E). A trans Golgi network formed by numerous small vesicles and tubules could also be found (Fig. 1E).

Prolonged postfixation with osmium tetroxide for $48 \mathrm{~h}$ in the presence of potassium iodide resulted in an effective electron-dense staining of specific cell compartments : the nuclear envelope, the Golgi complex, as well as a meshwork of short and long tubules scattered throughout the cytoplasm (Fig. 2A). Association of such tubular profiles with the nuclear envelope, the Golgi complex, and flagellar structure allowed us to identify them as endoplasmic reticulum cisternae (Fig. 2C). No reaction was observed in proacrosomal granule and the plasma membrane (Fig. 2D). 


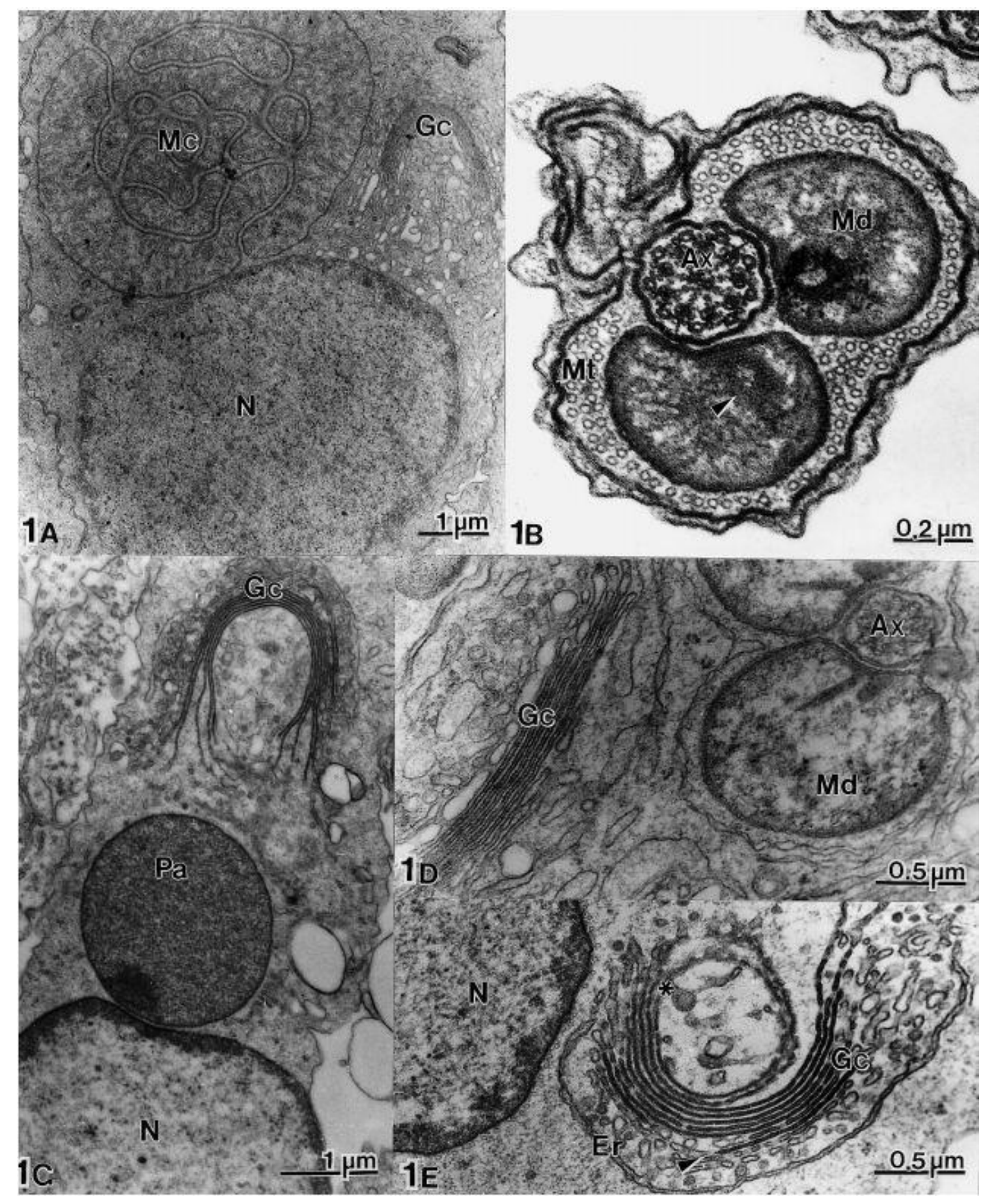

Fig. 1 (A) Spermatid of Euchistus heros in the initial stage of differentiation. The nucleus (N) seems like of a somatic cell; the cytoplasm contains a developed Golgi complex (Gc) and mitochondrial complex (Mc) 13,000x Transverse section of flagellar region of Nezara viridula spermatozoon, showing the axoneme $(A x)$ with 9+9+2 microtubule pattern, 2 mitochondrial derivatives (Md) containing 2 paracrystalline structures (arrowhead). Microtubules (Mt). 70,000x. (c) Early spermatid of N. viridula showing a single Golgi complex (Gc) close to the proacrosomal granule 9 (Pa) Nucleus (N)17,000 (D) Transverse section of flagellar region of $E$. heros spermatozoon showing a Golgi complex (Gc) near the flagellar structures. Axoneme (Ax) mitochondrial derivatives (Md).32,500x.(E) Spermatid of $N$ viridula showing a cisterna of the endoplasmic reticulum (Er)associated to the cis face (arrowhead) of the Golgi complex (Gc). A trans Golgi network (asterisk) could also be seen[ Nucleus (N)33,000x. 


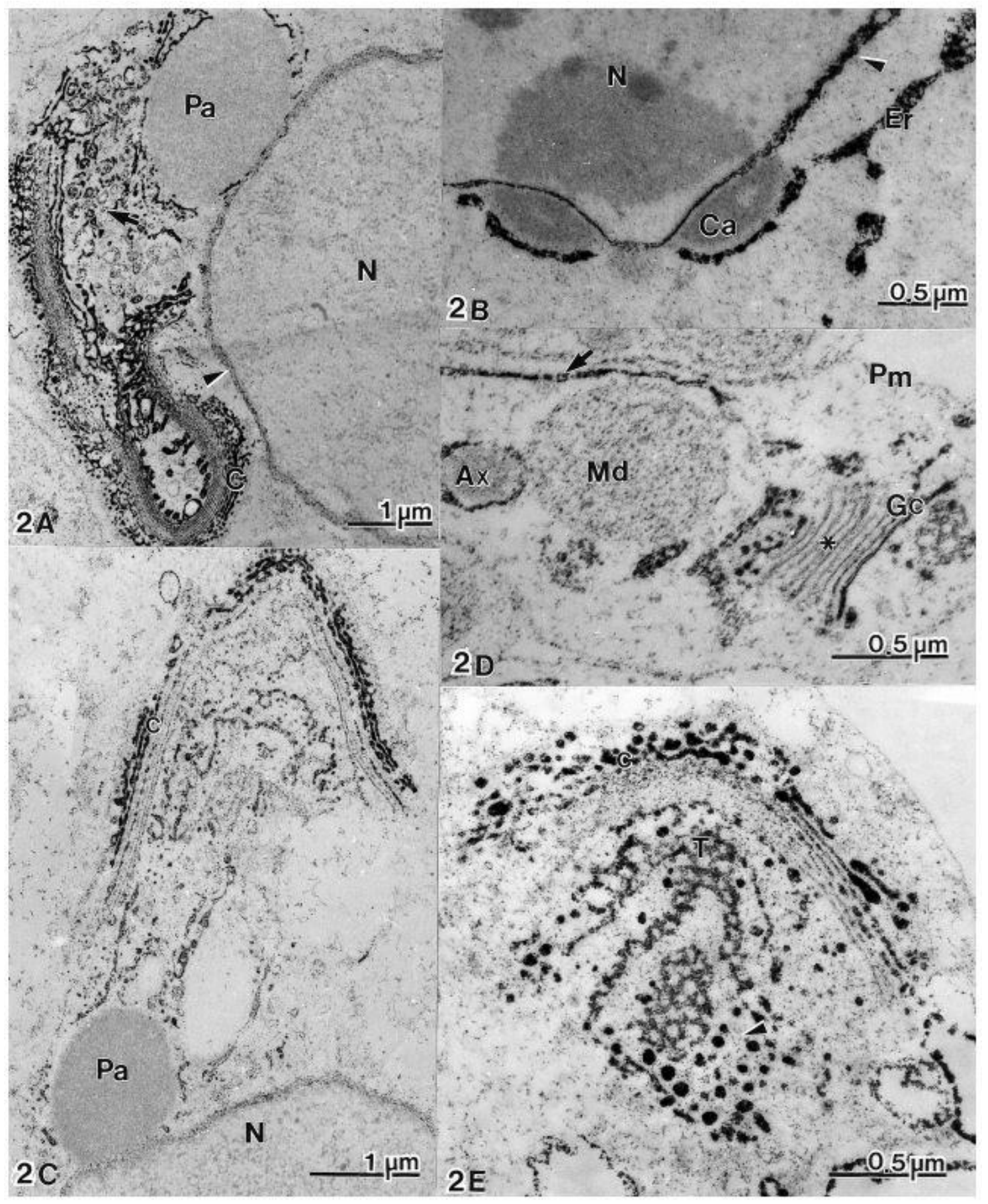

Fig. 2. Spermatids after a prolonged postfixation with osmium tetroxide in the presence of potassium iodide. in medial Golgi cisternae (asterisk). Axoneme (Ax); Mitochondrial derivatives (Md). 42,000x. (E) Spermatid of N. viridula showing positive reaction on the cis Golgi cisternae (C), as well as the trans Golgi network (T) and uncoated vesicles (arrowhead) associated to this region. 42,000x.

The Golgi complex compartments present a differentiated impregnation. The cis network and the cis Golgi cisternae, recognized by their close association with endoplasmic tubules, presented a strong positive reaction (Fig. 2 D, E), as well as the trans Golgi network, and uncoated vesicles associated with this region (Fig. 2E). On the other hand, reaction in the medial and trans Golgi cisternae was usually absent (Fig. 2C). 
Background staining was observed as finely granular deposits scattered throughout the cytoplasm.

\section{Discussion}

Heteropteran spermatozoa have common characteristics, which are not found in other insects : $2-3$ crystalline bodies within the mitochondrial derivatives and bridges between the mitochondrial derivatives and 2 of the axonemal microtubules (Afzelius et al., 1976; Afzelius et al., 1985; Dallai and Afzelius, 1980; Dolder, 1988; Báo and de Souza, 1994a). But, like other insects, the heteropteran spermatozoa possess a head containing nucleus and acrosome, and the tail, which, contains axoneme and mitochondrial derivatives.

Previous studies indicate that the acrosome of insects, as in higher animals, is formed by the Golgi complex (Phillips, 1970; Baccetti, 1972; Yasuzumi, 1974). In the majority of insects, where this process has been studied, the formation of a spherical body, the proacrosomal granule, occurs on the concave side of the Golgi complex. This vesicle, found in early spermatids, between the Golgi complex and nucleus, is gradually modified taking on a characteristic shape in the last stages of spermiogenesis (Báo et al., 1989; Ndiaye and Mattei, 1992). The association of an endoplasmic reticulum cisterna with the cis-face of the Golgi apparatus, as in secretory cells, is well known, and is also common during acrosome formation (Baccetti, 1975; Werner, 1989) that occurs simultaneously with nuclear transformation and flagellar formation in a typical insect spermiogenesis.

In this study, we used osmium tetroxide-potassium iodide (OsO4-KI) to show the Golgi complex-endoplasmic reticulum system of spermatids during differentiation process. The impregnation with OsO4-KI technique consists of the reduction of osmium tetroxide to osmium black after several hours of incubation, by combining osmium with labile S-S bridges present in newly made proteins, before they reach tertiary structure (Locke and Huie, 1983).The essential requirements for consistent staining of the vacuolar system, are osmium tetroxide in the presence of iodide. OsO4-KI acts slowly to break dissulfide bridges via the formation of osmium blacks, than the reaction required several hours at room temperature to produce the kind of staining shown.

This staining in Golgi complex suggests that these compartments have a reducing environment able to reduce osmium in the presence of potassium iodide; this result is also consistent with the fact that the spermatids are in a phase of differentiation, thus needing a continuous supply of proteins for this process. Indeed, it allows to see the participation of Golgi complex-endoplasmic reticulum system on the formation of acrosome and other 
structures like membranes surrounding the nucleus, the flagellar components and the axoneme. The staining of other structures on spermatic cell confirms the idea that all structures, except nucleus, mitochondria and axoneme, are derived from the Golgi complexendoplasmic reticulum system (Baccetti, 1975).

Since Bowen, 1924classical studies, the role of the Golgi complex in the formation of the acrosome is well established. A great number of electron microscopical investigations, beginning with Burgos and Fawcett, 1955, have extended our knowledge at the ultrastructural level (Werner, 1989). The Golgi complex is present during almost the entire period of spermatogenesis. Its prominent role, although restricted to early spermatid stages, is the formation of the acrosome (Werner and Werner, 1991). Previous studies have shown that the Golgi complex is fundamental to acrosome formation in Diptera (Perotti, 1969; Warner, 1971; Baccetti, 1972; Báo et al., 1989; Ndiaye and Mattei, 1992), as well as in Chrysomelidae (Báo, 1996) and Homoptera (Báo et al., 1997).

The acrosome may be considered with a secretory granule and a lysosome (Birns and Masek, 1961; Allison and Hartree, 1970); its formation serves as the first example of the role of the Golgi complex in the production of a 'primary lysosome (Goldfischer, 1982). The mammalian sperm acrosome, a membrane-bounded organelle in the sperm head, is derived from vesicles formed in the Golgi apparatus, as are primary lysosomes and secretory granules of somatic cells (Randall and Meizel, 1981).

The most important functions of the Golgi complex are the transport and terminal glycosylation of glycoproteins coming from the endoplasmic reticulum and destined to secretion granule, lysosomes and plasma membrane (Palade, 1975; Mellman and Simons, 1992). Recent studies on the Golgi complex of various cell types have shown the importance of the elements on the trans face of the stacks of saccules in the terminal glycosylation of proteins and in sorting and directing glycoproteins toward their destinations (Roth et al., 1985; Rothman, 1985; Griffiths and Simons, 1986; Taatjes and Roth, 1986; Thorne-Tjomsland et al., 1988). Golgi complex transition vesicules and saccules maintain an environment that is independent of the secretory material passing through them, it is detectable by OsKI staining (Locke and Huie, 1983).

When a routine fixation was used, only few profiles of endoplasmic reticulum could be observed, dispersed throughout the cytoplasm. Nevertheless, using osmium-KI impregnation we observed several profiles throughout the cytoplasm. This fact leads us to consider this technique as a powerful tool to study the distribution and participation of Golgi complexendoplasmic reticulum system on spermiogenesis of hemipteran insects. 
Acknowledgements

We thank Dr M. Borges for supplying the insects. This work was supported by Coordenação de Aperfeiçoamento de Pessoal de Nível Superior (CAPES), Conselho Nacional de Desenvolvimento Científico e Technológico (CNPq), Fundação de Amparo à Pesquisa do Distrito Federal (FAPDF) and Programa de Apoio a Núcleos de Excelência (Pronex).

\section{References}

Afzelius et al., 1976 Afzelius, B. A., Baccetti, B. and Dallai, R. (1976) The giant spermatozoon of Notonecta.Journal Subsmicroscopic Cytology8(2-3), 149-161.

Afzelius et al., 1985 Afzelius, B. A., Dallai, R. and Lindskog, P. (1985) Spermatozoa of saldid bugs (Insecta, Hemiptera, Leptopodomorpha). Journal of Ultrastructure Research90, 304-312.

Allison and Hartree, 1970 Allison, A. C. and Hartree, E. F. (1970) Lysosomal enzymes in the acrosome and their possible role in fertilization. Journal of Reproduction and Fertility21, 501515.

Baccetti, 1972 Baccetti, B. (1972) Insect sperm cells. Advance Insect Physiology9, 315-397.

Baccetti, 1975 Baccetti, B. (1975) The role of the Golgi complex during spermiogenesis. Current Topics on Developmental Biology10, 103-122.

Báo, 1996 Báo, S. N. (1996) Spermiogenesis in Coelomera lanio (Chrysomelidae : Galerucinae) : ultrastructural and cytochemical studies. In Chrysomelidae Biology Vol. 3 : GeneralStudies, ed. P. H. A. Jolivet and M. L. Cox, pp. 119-132. Academic Publishing, Amsterdam, The Netherlands.

Báo and de Souza, 1994a Báo, S. N. and de Souza, W. (1994a) Structural specialization in the flagellum of the spermatozoon of the bloodsucking bug (Rhodnius prolixus; Hemiptera, Reduviidae). Tissue and Cell26, 299-308.

Báo and de Souza, 1994b Báo, S. N. and de Souza, W. (1994b) Cytochemical localization of enzymes in the spermatid and the spermatozoon of Culex quinquefasciatus Say (Diptera: Culicidae). InternationalJournal of Insect Morphology and Embryology23, 57-67.

Báo et al., 1989 Báo, S. N., Quagio-Grassiotto, I. and Dolder, H. (1989) Acrosome formation in Ceratitiscapitata (Diptera, Tephritidae). Cytobios58, 93-100.

Báo et al., 1997 Báo, S. N., Kitajima, E. W., Callaini, G., Lupetti, P. and Dallai, R. (1997) Spermiogenesis in three species of whitefly (Homoptera, Aleyrodidae). Acta Zoologica (Stockholm) 78, 163-170.

Birns and Masek, 1961 Birns, M. and Masek, B. (1961) Localization of enzyme activities in frozen-substituted fixed cells. The Journal of Histochemistry and Cytochemistry9, 204. 
Bowen, 1924 Bowen, R. H. (1924) On the acrosome of the animal sperm. The Anatomical Record28, 1-13.

Burgos and Fawcett (1955) Burgos, M. H. and Fawcett, D. W. (1955) Differentiation of the spermatids in the cat (Felisdomestica). Journal of Biophysics and Biochemistry Cytology1, 287300.

Dallai and Afzelius, 1980 Dallai, R. and Afzelius, B. A. (1980) Characteristics of the sperm structure in Heteroptera (Hemiptera, Insecta). Journal of Morphology164, 301-309.

Dolder, 1988 Dolder, H. (1988) Cytoskeletal bridges between organelles in sperm flagellum of Triatomainfestans (Hemiptera, Reduviidae). Journal of Ultrastructure and Molecular Structure Research101, 159-164.

Fawcett et al., 1971 Fawcett, D. W., Anderson, W. A. and Phillips, D. M. (1971) Morphogenetic factors influencing the shape of the sperm head. Developmental Biology26, 220-251.

Goldfischer, 1982 Goldfischer, S. (1982) The internal Reticular Apparatus of Camillo Golgi : A complex, heterogeneous organelle, enriched in acid, neutral, and alkaline phosphatases, and involved in glycosylation, secretion, membrane flow, lysosome formation and intracellular digestion. TheJournal of Histochemistry and Cytochemistry30(7), 717-733.

Griffiths and Simons, 1986 Griffiths, G. and Simons, K. (1986) The trans Golgi network : Sorting at the exit site of the Golgi complex. Science234, 438-443.

Locke and Huie, 1983 Locke, M. and Huie, P. (1983) The mystery of unstained Golgi complex cisternae. The Journal of Histochemistry and Cytochemistry31(8), 1019-1032.

Mellman and Simons, 1992 Mellman, I. and Simons, K. (1992) The Golgi complex : in vitro veritas? Cell68, 829-840.

Ndiaye and Mattei, 1992 Ndiaye, M. and Mattei, X. (1992) Particularity of acrosome formation during spermiogenesis in two mosquitoes : Toxorhynchites brevipalpis and Anopheles gambiae. JournalSubmicroscopic Cytology and Pathology24, 269-272.

Palade, 1975 Palade, G. E. (1975) Intracellular aspects of the process of protein secretion. Science189, 347-358.

Perotti, 1969 Perotti, M. E. (1969) Ultrastructure of the mature sperm of Drosophila melanogaster Meig. Journal Submicroscopic Cytology1, 171- 196.

Phillips, 1970 Phillips, D. M. (1970) Insect sperm : their structure and morphogenesis. The Journal of Cell Biology44, 243-277.

Randall and Meizel, 1981 Randall, J. M. and Meizel, S. (1981) Potassium ion influx and Na+, K+ATPase activity are required for the hamster sperm acrosome reaction. The Journal of Cell Biology91, 77-82.

Roth et al., 1985 Roth, J., Taatjes, D. J., Lucocq, J. M., Weinstein, J. and Paulson, J. C. (1985) Demonstration of an extensive trans-tubular network continuous with the Golgi apparatus stack that may function in glycosylation. Cell43, 287-295. 
Rothman, 1985 Rothman, J. E. (1985) The compartmental organization of the golgi apparatus. ScientificAmerican253, 74-89.

Taatjes and Roth, 1986 Taatjes, D. J. and Roth, J. (1986) The trans-tubular network of the hepatocyte Golgi apparatus is part of the secretory pathway. Europeane Journal of Cell Biology42, 344-350.

Thorne-Tjomsland et al., 1988 Thorne-Tjomsland, G., Clermont, Y. and Hermo, L. (1988) Contribution of the Golgi apparatus components to the formation to the acrosomic system and chromatoid body in rat spermatids. The Anatomical Record221, 591-598.

Tokuyasu, 1974 Tokuyasu, K. T. (1974) Dynamics of spermiogenesis in Drosophila melanogaster. IV. Nuclear transformation. Journal of Ultrastructure Research48, 284-303.

Warner, 1971 Warner, F. D. (1971) Spermatid differentiation in the blowfly Sarcophaga bullata with particular reference to flagellar morphogenesis. Journal of Ultrastructure Research35, 210-232.

Werner, 1989 Werner, G. (1989) Associated membranes in spermatocytes of the backswimer, Notonectaglauca L. (Heteroptera : Hydrocorisae). International Journal of Insect Morphology and Embryology18, 275-280.

Werner and Werner, 1991 Werner, G. and Werner, K. (1991) Golgi apparatus in spermatocytes of the waterstrider, Gerrisnajas Deg. (Heteroptera). Journal Submicroscopic Cytology and Pathology23, 519-524.

Yasuzumi, 1974 Yasuzumi, G. (1974) Electron microscope studies on spermiogenesis in various animal species. International Review of Cytology37, 53-120. 